Гацаева P.C-A.

\title{
Современные методы преподавания математики в техническом вузе
}

Чеченский государственный университет (Россия, Грозньй)

doi: $10.18411 / \mathrm{j}-06-2021-164$

\section{Аннотация}

В статье рассматриваются совокупность методов, приемов, способов, средств создания педагогических условий на основе компьютерной техники, средств телекоммуникационной связи.

Ключевые слова: Модуль, математика, компьютерные учебники, информационные технологии, мультимедийные курсы, силлабус, информатизация образования.

\section{Abstract}

The article discusses a set of methods, techniques, methods, means of creating pedagogical conditions on the basis of computer technology, telecommunication means.

Keywords: Module, mathematics, computer textbooks, information technology, multimedia courses, syllabus, informatization of education.

Изменение учебных планов и сокращение часов на изучение математики в вузе требуют внедрения новых методов обучения, которые позволят за достаточно короткий срок передать студентам большой объем знаний, обеспечить высокий уровень овладения изучаемым материалом и закрепления его на практике.

Как в этих условиях сделать процесс обучения более эффективным? Ответом на этот вопрос остается постоянное совершенствование преподавателем своих профессиональных навыков, активное овладение новыми приемами, средствами и методами оптимального управления учебно-познавательной деятельностью студентов за счет внедрения в учебный процесс современных технологий обучения.

Практика обучения требует постоянного повышения качества педагогического процесса, поиска путей его оптимизации. На современном этапе развития образования многие методические инновации связаны с применением информационных технологий обучения.

В научно-методической литературе под информационными технологиями обучения (ИТО) понимается совокупность методов, приемов, способов, средств создания педагогических условий на основе компьютерной техники, средств телекоммуникационной связи и интерактивного программного продукта, моделирующих часть функций педагога по представлению, передаче и сбору информации, организации контроля и управления познавательной деятельностью.[3]

Существует два подхода к определению информационной технологии обучения. В первом случае речь идет об информационных технологиях обучения как процессе обучения, а во втором случае - о применении информационных технологий в обучении как элементов обучения. К первой группе технологий можно отнести дистанционное обучение, а ко второй - мультимедийные технологии, позволяющие объединять различные формы представления информации в единый учебный комплекс.

Применение информационных технологий в учебном процессе предоставляет принципиально новые возможности для активизации обучения, позволяет сделать аудиторные занятия более интересными и динамичными.

Структура учебного занятия с использованием интерактивных устройств может меняться. Любое занятие, в том числе и с использованием интерактивных технологий, должно иметь четкий план и структуру, достигать определенных целей и результатов. 
Основная цель планирования учебной деятельности при изучении математики с помощью компьютерных технологий обучения - индивидуально подобранная для каждого студента последовательность информационных блоков и учебных заданий.

В свете всего вышесказанного, на наш взгляд, при выборе технологии обучения оптимальной является технология, при которой создается учебно-методический комплекс (УМК) по определенному курсу. В состав этого комплекса входят силлабус (программа курса), учебный материал курса, практические задания, интерактивные тесты для самоконтроля, методические рекомендации по самостоятельному изучению курса, контрольные вопросы и задания для текущего и итогового контроля, глоссарий, список рекомендуемой литературы.

Возможность учета индивидуальных особенностей учащихся - одна из наиболее сильных сторон информационных средств обучения. При этом меняются функции преподавателя. Если в традиционном обучении основная функция преподавателя информационное обеспечение, то теперь ведущая функция преподавателя - управление познавательной деятельностью учащегося, включающее планирование, организацию и контроль процесса обучения в составе следующих задач:

1) разработка структуры учебного предмета и определение количества и содержания модулей;

2) наполнение содержанием каждого модуля;

3) разработка перечня вопросов и тем для самостоятельной работы, усвоения и закрепления знаний;

4) разработка тестов и вопросов для проверки знаний.

Это приводит к необходимости поиска новых моделей занятий, форм проведения итогового контроля, повышает индивидуальность и интенсивность обучения.

В иерархии организационных форм обучения математике во втузе предусматривается такое расположение: лекции, практические занятия, самостоятельная работа студента под руководством преподавателя (СРСП), самостоятельная работа студента (СРС).

Современная задача преподавателя высшей школы - повышение качества математического образования. От того, как педагог владеет технологическими приемами обучения, как умеет их адаптировать к конкретным условиям обучения студентов, зависит результативность учебного процесса.

Изменение средств обучения, как и изменение в любом звене дидактической системы, неизбежно приводит к перестройке всей системы. Использование информационных технологий расширяет возможности преподавателя, однако, это лишь инструмент, метод решения педагогических задач. Не следует забывать, что в основе любого учебного процесса лежит педагогическая технология, информационные образовательные ресурсы должны не заменить, а сделать технологию более результативной.[1]

На наш взгляд, нужны разнообразные формы учебной деятельности: фронтальная работа по актуализации знаний, групповая или парная работа по овладению конкретными учебными умениями, устные и письменные задания; необходимо разумное сочетание инноваций и традиций.

Также применение новых информационных технологий в преподавании математики предполагает обеспечение студентов методическими и учебными материалами нового типа - компьютерными учебниками. В связи с этим появляется необходимость в разработке новых методических приёмов и обновлении методической системы преподавания математики.

Значительная часть преподавателей, особенно старшего поколения, оказалась на сегодня не готовой к использованию информационных технологий в учебном процессе. Также многие преподаватели сдержанно относятся к внедрению новых технологий в 
традиционный учебный процесс по причине значительного усложнения педагогической деятельности. Поэтому чаще всего использование в учебном процессе информационных технологий обучения ограничивается чтением лекций, подготовленных в виде презентаций PowerPoint в аудиториях, оснащенных компьютером и проектором, и проведением итогового контроля в компьютерной форме.

Кроме этого, низкий процент использования компьютерных технологий обучения в вузе во многом связан с отсутствием соответствующих программных средств и методик по их использованию. Один из способов решения этой проблемы создание мультимедийных курсов по различным разделам математики и обучение преподавателей проектированию и внедрению в учебный процесс современных средств и методов обучения, чтобы любой преподаватель мог самостоятельно и эффективно совершенствовать свою учебно-педагогическую деятельность.

Новые информационные технологии обучения ускоряют адаптацию педагога в условиях информатизации образования с формированием оптимальной для каждого конкретного преподавателя системы приемов, методов и средств управления учебнопознавательной деятельностью студентов с учетом профессионального опыта преподавателя, его индивидуально-психологических особенностей и сформировавшегося стиля преподавания.

Учебный процесс постоянно должен быть ориентирован на внедрение новых образовательных технологий. Обладая определенной гибкостью, дающей возможность варьировать цели, средства, методы обучения, информационные образовательные технологии работают на формирование устойчивого познавательного интереса к изучаемым дисциплинам.

Таким образом, существуют разные типы и виды технических средств обучения, методов и методик преподавания, новых информационных технологий, предоставляющие огромные возможности совершенствования организации учебного процесса, содержания, форм и методов обучения в вузе.

$$
* * *
$$

1. Жангисина Г.Д. Педагогика для технических вузов. - Алматы: АТУ, 2006.

2. Кулекеев Ж.А. и др. Системы менеджмента качества организаций высшего и профессионального образования. - Караганда: КарГТУ, 2004.

3. Основы открытого образования. Под ред. В.И. Солдаткина. - М.: НИИЦ РАО, 2002.

4. Смирнов С.А. Педагогика: педагогические теории, системы, технологии. - М., 1999.

5. Шакаримова А.Б., Криулько Н.С., Хегай О.М. Дистанционное обучение (опыт реализации в ВКГТУ) / Под общей редакцией д.т.н., профессора Мутанова Г.М.- Усть-Каменогорск: ВКГТУ, 2006.

Гацаева P.C-A.

\section{Социально - культурная характеристика моноэтнического региона на примере Чеченской республики}

Чеченский государственный университет (Россия, Грозньй)

doi: $10.18411 / \mathrm{lj}-06-2021-165$

\section{Аннотация}

В статье выявляются социально - педагогические проблемы воспитания современной молодежи. Социально - педагогические проблемы воспитания современной молодежи, обосновываются и предлагаются решения обозначенных проблем формирования духовно целостной личности.

Ключевые слова: межэтническая культура, толерантность, этническая культура, этническая идентичность, макросреда, микросреда, личность, социум. 